AGRICULTURE AND BIOLOGY JOURNAL OF NORTH AMERICA

ISSN Print: 2151-7517, ISSN Online: 2151-7525, doi:10.5251/abjna.2011.2.6.902.906

(C) 2011, ScienceHu $\beta$, http://www.scihub.org/ABJNA

\title{
Bioreactors in out-door plastic tanks: the effects of microbial protein on the growth, feed utilization and haematology in Oreochromis niloticus (linnaeus) fingerlings
}

\author{
F.G. Bob-Manuel \\ Rivers State University of Education, Rumuolumeni, P. M. B. 5047, \\ Port Harcourt, Nigeria
}

\begin{abstract}
A study was carried out to assess the in situ production of microbial protein in outdoor experimental tanks for the culture of Oreochromis niloticus. This was compared with pelleted $30 \%$ protein diet. The results indicated that there was no significant difference in growth and nutrient utilization between the $30 \%$ protein pelleted diet and the diets in which the microbial protein was produced in the tanks at $(P>0.05)$ Also analysis of the blood parameters did not give a significant difference in the values obtained for PCV, Hb, Wbc, MCHC, Lct, ESR and platelets at $(P>0.05)$ between the control and the microbial protein produced in the experimental tanks
\end{abstract}

Keywords: Bioreactors, plastic tank, microbial proteins, feeding, O. niloticus and haematology

\section{INTRODUCTION}

The major challenge facing tilapia nutritionists in developing countries is the development of commercial cost effective fish feeds using locally available, cheap, and unconventional resources. Fishmeal is still generally the preferred protein source for use within compound aqua feeds for tilapia, because of its high nutritional quality and biological value to fish. Nutrition is the most expensive component in intensive aquaculture industry where it represents over $50 \%$ of operating cost. Moreover, protein itself represents about $50 \%$ of feed cost in intensive culture.

One possibility of reducing the feed cost is to upgrade feed materials in the pond through the use of microbial protein synthesis (Oliva-Teles and Groncalves 2001; Olivera-Novoa et al 2002). The proposal is therefore an in situ production and utilization of microbial proteins which is highly accessible to fish; thus short circuiting the high processing cost (Ansa and Jiya 2002; Li and Gatlin 2003).

Under pond farming conditions, micro-organisms constitute a natural food organism for tilapia in the form of periphytic mats and detrital biomass with species such as Oreochromis niloticus being capable of directly filtering particulate matter and microorganisms from the water column (Avnimelech and Mokady 1986). They also reported that $O$. aureus fed microbially produced Single cell protein (SCP) grew as well as fish fed a protein-rich pellet.
The heterotrophic food web as a source of feed for fish through microbial composition of organic residues added to the pond has been discussed earlier (Scheoder 1978; Avnimelech and Mokady 1986). The central process in this heterotrophic food web is the production of Microbial protein or Single Cell Protein (SCP). One factor which favors the uptake by fish of microbial cells is the flocculation of these cells and formation of relatively large clusters (Avnimelech et al. 1989).

The application of haematological studies to investigation of animal and human disease process is well accepted and considered to be a routine procedure in diagnostic studies. There have been attempts to apply haematological parameters to study of abnormal physiological processes in fish. The importance of fish haematology in dietary studies lie in the fact that internal physiological changes caused by dietary composition may be reflected in the blood characteristics of the cultured fish (Sanchez et al., 1979; Salami et al. 1992; Klinger et al., 1996; Akinwade 2004).

Salami et al; (1992) and Akinwade et al., (2004), considered the effects of nutrition in haematology parameters of $C$. gariepinus and $H$. bidorsalis respectively. There is a dearth of information on the influence of SCP on warm water fish species. However, there are a few reports on some temperate fish species (Le Ray et al; 1986; Greene and Selivonchick, 1990; Wise et al., 1993).

The objective of this work is therefore to assess the growth response of $O$. niloticus to various microbial 
protein diets; determine the feed utilization and evaluate the effect of feed on blood parameters.

\section{MATERIALS AND METHODS}

The work was carried out in 20 outdoor plastic tanks in the Department of Biology, Rivers State University of Education, Rumuolumeni, Port Harcourt. The fingerlings were assigned randomly to the tanks at a stocking density of thirty (30) fish per tank, giving a total of six hundred (600) fingerlings. The experimental tanks have dimensions of $52 \mathrm{~cm} \times 36 \mathrm{~cm}$ $\mathrm{x} 32 \mathrm{~cm}$

The fingerling $3.0 \mathrm{~g}$ initial body weights were obtained from the African Regional Aquaculture Centre (ARAC) in Aluu, near Port Harcourt, Rivers State, Nigeria. Before stocking, the fish, the plastic tanks were washed with tap water and dried to avoid the presence of contaminating organism and $3 / 4$ filled with water. The fish was stocked and allowed to acclimate for four days. At the end of the acclimation period the fish were weighed in groups of (30) thirty into each plastic tank. The experimental design consisted of five treatments and four replicates making a total of twenty experimental units. A complete randomization design (CRD) was used to avert differences and variabilities in the treatments arising from environmental factors.

The experimental diets used in the research were as follows.

$$
\begin{aligned}
& X_{A}=30 \% \text { fishmeal pelleted diet (control) } \\
& X_{B}=50 \% \text { SCP substituted fishmeal diet } \\
& X_{C}=\text { Poultry waste }+ \text { wheat bran } \\
& X_{D}=\text { Cow dung }+ \text { wheat bran } \\
& X_{E}=\text { Goat excreta }+ \text { wheat bran }
\end{aligned}
$$

Feed Preparation and Feeding Procedure: Diet $X_{A}$ was prepared as pelleted diet with $30 \%$ fishmeal. This diet served as the control.

Diet $X_{B}$ was formulated as $30 \%$ fishmeal diet in which $50 \%$ of the fish meal protein was substituted with yeast SCP.

Diet $\mathrm{X}_{C}$ consisted of $20 \%$ poultry waste and $80 \%$ wheat bran.

Diet $X_{D}$ consisted of $20 \%$ cow dung and $80 \%$ wheat bran

Diet $\mathrm{X}_{E}$ consisted of $20 \%$ goat excreta and $80 \%$ wheat bran.

The raw poultry waste, cow dung and goat excreta were obtained locally from local poultry farmers, the abatoire, and local goat rearers respectively all at
Rumuolumeni near Port Harcourt. They were spread out on plastic trays and sun dried for two weeks. They were then milled with mortar and pestle into fine particles. This was then mixed with the wheat bran in the proportions earlier mentioned. They were wrapped separately in different polyethylene bags.

Fish were fed daily on experimental diet at $3 \%$ of their body weight twice daily at $0900 \mathrm{hr}$ and $1500 \mathrm{hrs}$. Feeding was done by hand; and the fish were fed 6 days in a week, and left to browse on the leftover feed on the seventh day. The feeding trial lasted for 8 weeks.

Growth and Feed Utilization Parameter: The growth rate of fish fed with the experimental diets were expressed as changes in the average fish body weight and percentage weight gain during the experimental period. The percentage weight gain (PWG), the specific growth rate (SGR) and feed conversion ratio (FCR) for the fish feed were computed using the following expressions.

$$
\begin{aligned}
& \text { PWG }=\frac{\text { Mean weight gain }}{\text { Mean fish weight }} \times 100 \\
& \operatorname{SGR}(\% / \text { day })=\underline{\log _{\underline{e}}} \underline{\underline{W}_{2}} \underline{\underline{2}} \underline{-\log _{2}} \frac{\underline{W}_{1}}{T_{1}} \\
& \text { Where: } W_{1} \text { - initial weight } \\
& W_{2} \text { - final weight } \\
& \mathrm{T}_{1} \text { - initial time } \\
& \mathrm{T}_{2} \text { - final time } \\
& \mathrm{FCR}=\frac{\text { Dry feed fed }(\mathrm{g})}{\text { Wet weight gain }(\mathrm{g})}
\end{aligned}
$$

Blood Collection and Analyses Procedure: Blood collection was done by cardiac puncture. This was done by introducing/inserting the needle of a syringe at the ventral part of the fish between the ' $\mathrm{V}$ ' created by the opercular bones. Blood was drawn into the syringe and put into blood vials containing EDTA (anti coagulant). The blood so collected from each treatment was sent for analysis.

The following blood parameters were analysed; haemoglobin $(\mathrm{Hb})$; Packed cell volume (PCV); White blood corpuscles (WBC) Mean corpuscular haemoglobin concentration (MCHC); leucocrit (LCT) Erythrocyte sedimentation rate (ESR) and Platelets. The haemoglobin $(\mathrm{Hb})$ was analysed using the cyanmethahaemoglobin method, the PCV using an adaptation of the microhaematocrit method used in human haematology (Sniezko, 1960), WBC was carried out by the use of Dacies fluid (Dacie and 
Lewis 1968), and an improved Neubauer counting chamber (Haemocytometer); MCHC was analysed by the following relationship (Brown 1980) .

$$
\frac{\text { Haemoglobin }}{\text { Haematocrit or PCV }} \times \frac{100}{1}
$$

The leucocrit value was calculated as the volume of packed Leucocyte as a percentage of whole blood volume (Wedemeyer et al. 1984). ESR was measured by an adaptation of the standard Wintrob method (using capillary tubes i.e., micro-Wintrobe method (Blaxhall and Daisley, 1973). For the platelets count the Ree and Ecker method (Brown 1980) was used.

Statistical Analysis: The results obtained were subjected to analysis of variance tests based on Wahua (1999) Duncan Multiple range test was used to find significant differences between values

\section{RESULTS}

The percentage weight gain (PWG) in O. niloticus fed with the diets for eight weeks is given in Table I

Table 1: Percentage weight gain (PWG) in O. niloticus fed with various diets for eight weeks

\begin{tabular}{|c|c|c|c|c|c|c|c|c|}
\hline \multicolumn{9}{|c|}{ Experimental Period in Weeks } \\
\hline Diets & 1 & 2 & 3 & 4 & 5 & 6 & 7 \\
\hline $\mathrm{X}_{\mathrm{A}}$ & $0.95^{\mathrm{a}}$ & $0.82^{\mathrm{b}}$ & $0.80^{\mathrm{b}}$ & $1.5^{\mathrm{b}}$ & $0.92^{\mathrm{a}}$ & $1^{\mathrm{a}}$ & $0.4^{\mathrm{a}}$ & $1.9^{\mathrm{b}}$ \\
\hline $\mathrm{X}_{\mathrm{B}}$ & $0.82^{\mathrm{c}}$ & $0.62^{\mathrm{c}}$ & $1.32^{\mathrm{b}}$ & $1.70^{\mathrm{a}}$ & $1.70^{\mathrm{c}}$ & $0.08^{\mathrm{b}}$ & $0.8^{\mathrm{c}}$ & $1.63^{\mathrm{a}}$ \\
\hline $\mathrm{X}_{\mathrm{C}}$ & $0.7^{\mathrm{b}}$ & $1.5^{\mathrm{a}}$ & $0.9^{\mathrm{b}}$ & $1.7^{\mathrm{a}}$ & $1.8^{\mathrm{a}}$ & $1.6^{\mathrm{a}}$ & $0.92^{\mathrm{b}}$ & $1.9^{\mathrm{a}}$ \\
\hline $\mathrm{X}_{\mathrm{D}}$ & $0.7^{\mathrm{b}}$ & $1.3^{\mathrm{a}}$ & $0.9^{\mathrm{b}}$ & $1.05^{\mathrm{a}}$ & $0.6^{\mathrm{b}}$ & $1.03^{\mathrm{a}}$ & $1.05^{\mathrm{a}}$ & $0.92^{\mathrm{b}}$ \\
\hline $\mathrm{X}_{\mathrm{E}}$ & $1.3^{\mathrm{a}}$ & $1.6^{\mathrm{a}}$ & $0.8^{\mathrm{b}}$ & $1.09^{\mathrm{a}}$ & $0.83^{\mathrm{b}}$ & $1.4^{\mathrm{a}}$ & $0.8^{\mathrm{b}}$ & $1.93^{\mathrm{a}}$ \\
\hline
\end{tabular}

Figures in the same horizontal row having similar superscripts are not significantly different at $(\mathrm{P}>0.05)$.

The specific growth rate (SGR) of $O$. niloticus fed with the diets for eight weeks is given in table 2 .

Table 2. Specific Growth Rate (SGR) in O. niloticus fed with various diets for eight weeks

\begin{tabular}{|c|c|c|c|c|c|c|c|c|}
\hline \multicolumn{9}{|c|}{ Experimental Period in weeks } \\
\hline Diets & 1 & 2 & 3 & 4 & 5 & 6 & 7 & 8 \\
\hline $\mathbf{X}_{\mathrm{A}}$ & $0.9^{\mathrm{b}}$ & $0.1^{\mathrm{b}}$ & $1.5^{\mathrm{a}}$ & $0.1^{\mathrm{b}}$ & $1.5^{\mathrm{a}}$ & $0.1^{\mathrm{b}}$ & $1.5^{\mathrm{a}}$ & $0.2^{\mathrm{b}}$ \\
\hline $\mathrm{X}_{\mathrm{B}}$ & $0.09^{\mathrm{b}}$ & $0.6^{\mathrm{b}}$ & $0.09^{\mathrm{b}}$ & $0.6^{\mathrm{b}}$ & $0.9^{\mathrm{b}}$ & $0.7^{\mathrm{b}}$ & $0.9^{\mathrm{b}}$ & $0.7^{\mathrm{b}}$ \\
\hline $\mathrm{X}_{\mathrm{C}}$ & $0.1^{\mathrm{b}}$ & $1.4^{\mathrm{b}}$ & $0.1^{\mathrm{b}}$ & $1.4^{\mathrm{a}}$ & $1.2^{\mathrm{b}}$ & $1.4^{\mathrm{a}}$ & $0.2^{\mathrm{b}}$ & $1.4^{\mathrm{a}}$ \\
\hline $\mathrm{X}_{\mathrm{D}}$ & $0.7^{\mathrm{b}}$ & $1.7^{\mathrm{b}}$ & $0.8^{\mathrm{b}}$ & $1.8^{\mathrm{b}}$ & $0.4^{\mathrm{b}}$ & $1.2^{\mathrm{a}}$ & $1.4^{\mathrm{b}}$ & $0.2^{\mathrm{a}}$ \\
\hline $\mathrm{X}_{\mathrm{E}}$ & $1.3^{\mathrm{a}}$ & $1.2^{\mathrm{b}}$ & $1.3^{\mathrm{a}}$ & $0.2^{\mathrm{b}}$ & $1.3^{\mathrm{b}}$ & $1.2^{\mathrm{a}}$ & $0.3^{\mathrm{b}}$ & $1.3^{\mathrm{a}}$ \\
\hline
\end{tabular}

Figures in the same horizontal row having similar superscripts are not significantly different at $(\mathrm{P}>0.05)$ The feed conversion ratio (FCR) of $O$. niloticus fed with the diets for eight weeks is given in table 3

Table 3. Feed Conversion Ratio (FCR) in O. niloticus fed with various Diets for eight Weeks

\begin{tabular}{|c|c|c|c|c|c|c|c|c|}
\hline \multicolumn{9}{|c|}{ Experimental diets in weeks } \\
\hline Diets & 1 & 2 & 3 & 4 & 5 & 6 & 7 & 8 \\
\hline $\mathrm{X}_{\mathrm{A}}$ & $1.6^{\mathrm{a}}$ & $1.1^{\mathrm{a}}$ & $1.8^{\mathrm{a}}$ & $1.1^{\mathrm{a}}$ & $1.2^{\mathrm{a}}$ & $0.8^{b}$ & $0.8^{\mathrm{b}}$ & $1.0^{\mathrm{a}}$ \\
\hline $\mathrm{X}_{\mathrm{B}}$ & $1.4^{\mathrm{a}}$ & $0.8^{b}$ & $1.1^{\mathrm{a}}$ & $1.3^{\mathrm{a}}$ & $1.1^{b}$ & $1.0^{\mathrm{a}}$ & $1.1^{\mathrm{a}}$ & $1.0^{\mathrm{a}}$ \\
\hline $\mathrm{X}_{\mathrm{C}}$ & $0.5^{b}$ & $1.0^{\mathrm{a}}$ & $1.8^{a}$ & $1.3^{\mathrm{a}}$ & $1.2^{\mathrm{a}}$ & $1.3^{\mathrm{a}}$ & $1.4^{\mathrm{a}}$ & $1.3^{\mathrm{a}}$ \\
\hline $\mathrm{X}_{\mathrm{D}}$ & $0.7^{b}$ & $0.9^{b}$ & $1.5^{\mathrm{a}}$ & $1.2^{\mathrm{a}}$ & $1.5^{\mathrm{a}}$ & $1.3^{\mathrm{a}}$ & $1.3^{\mathrm{a}}$ & $1.4^{\mathrm{a}}$ \\
\hline$X_{E}$ & $1.3^{\mathrm{a}}$ & $1.2^{\mathrm{b}}$ & $1.3^{a}$ & $0.2^{\mathrm{b}}$ & $1.3^{b}$ & $1.2^{\mathrm{a}}$ & $0.3^{b}$ & $1.3^{\mathrm{a}}$ \\
\hline
\end{tabular}

Figures in the same horizontal row having similar superscripts are not significantly different at $(P>0.05)$.

The analysis of the blood parameters in O. niloticus fed with the various diets is given in table 4. 
Agric. Biol. J. N. Am., 2011, 2(6): 902-906

Table 4. Analysis of blood parameter in O. niloticus is given in table 4

\begin{tabular}{|c|c|c|c|c|c|}
\hline \multicolumn{6}{|c|}{ Experimental diet in weeks } \\
\hline Blood Parameters & $\mathbf{X}_{\mathrm{A}}$ & $\mathbf{X}_{\mathrm{B}}$ & $\mathrm{X}_{\mathrm{C}}$ & $\mathbf{X}_{\mathrm{D}}$ & $\mathrm{X}_{\mathrm{E}}$ \\
\hline PCV (\%) & $9^{a}$ & $7.8^{\mathrm{a}}$ & $7.3^{\mathrm{a}}$ & $7.8^{\mathrm{a}}$ & $8^{\mathrm{a}}$ \\
\hline HB g/d & $2.9^{\mathrm{a}}$ & $2.4^{\mathrm{a}}$ & $2.5^{\mathrm{a}}$ & $2.5^{\mathrm{a}}$ & $2.6^{\mathrm{a}}$ \\
\hline WBC X $10 \mathrm{~g} / \mathrm{l}$ & $8^{a}$ & $7.6^{\mathrm{a}}$ & $9.3^{\mathrm{a}}$ & $11.3^{\mathrm{a}}$ & $10.5^{\mathrm{a}}$ \\
\hline MCHC (\%) & $31.5^{\mathrm{a}}$ & $30.6^{\mathrm{a}}$ & $33.6^{\mathrm{a}}$ & $30.5^{\mathrm{a}}$ & $30.9^{\mathrm{a}}$ \\
\hline LCT (\%) & $3.4^{\mathrm{a}}$ & $3.0^{\mathrm{a}}$ & $2.1^{\mathrm{a}}$ & $3.5^{\mathrm{a}}$ & $2.6^{\mathrm{a}}$ \\
\hline ESR $\mathbf{m m ~ h r}$ & $5.3^{\mathrm{a}}$ & $7.8^{\mathrm{a}}$ & $6.6^{\mathrm{a}}$ & $7.8^{\mathrm{a}}$ & $5.5^{\mathrm{a}}$ \\
\hline Platelet x $10 \mathrm{~g} / \mathrm{l}$ & $136.3^{\mathrm{a}}$ & $95^{\mathrm{a}}$ & $86.3^{\mathrm{a}}$ & $123^{\mathrm{a}}$ & $137.5^{\mathrm{a}}$ \\
\hline
\end{tabular}

Figures in the same horizontal row having similar superscripts are not significantly different at $(P>0.05)$.

\section{DISCUSSION}

The percentage weight gain (PWG) did not give any significant difference between the various treatments at $(P>0.05)$ although differences occurred on weekly basis (Table 1). This is an indication that in situ production of single cell protein in the rearing tanks gave an equivalent weight gain as the control which consisted of fishmeal protein. Generally diet $X_{B}$ (which consist of $30 \%$ fishmeal in which $50 \%$ was substituted with SCP) gave a relatively lower PWG than the rest of the treatments. This may be attributable to the non-palatability of the SCP substituted diet.

The values of the specific growth rate did not differ significantly between treatments at $(P>0.05)$ although generally low values were recorded for diet $X_{B}$ (Table 2). This may also be due to the non-acceptability of the diet as a result of palatability problems.

The feed conversion ratio (FCR) values did not show a significant difference between treatments at $(P>0.05)$, Table 3. However the goat excreta SCP gave a relatively higher FCR values throughout the experimental period. The above findings were in agreement with those of Avnimelech and Mokady (1986) who reported that O. aureus fed microbially, produced diet grew as well as those fed with proteinrich pellets.

The blood analysis namely the PCV, $\mathrm{Hb}, \mathrm{WBC}$, MCHC LCT ESR platelets did not show any significant difference (Table 4) between treatments at $(P>0.05)$. This is an indication that the use of poultry waste, cow dung and goat excreta in combination with wheat bran for the in situ production of microbial protein in tilapia culture did not adversely affect the blood parameters as compared to the pelleted feeds.
It could therefore be inferred from the foregoing that dried poultry waste, cow dung and goat excreta in combination with wheat bran could generate microbial protein in fish pond where the wheat bran served as carbon source for the microbial flora in these wastes to multiply thereby producing single cell protein which served as food for $O$. niloticus fingerlings. It could be deduce from the result of the growth and nutrient utilization parameters in this work that the introduction of the wheat bran as carbon source in the fish pond may have been utilized by the resident microbial flora in the various organic wastes to multiply. Thus producing an heterotrophic food web in the fish tanks for the fish to feed.

This is in line with the findings of (Shroeder 1978; Oliva-Teles and Groncalves 2001; Ansa and Jiya 2002). The result of the haemalological parameter analysed goes to confirm that the use, of microbial protein in the experimental tanks did not adversely impact on blood parameters compared with the control.

\section{CONCLUSION}

It would therefore be concluded from the findings in this study that it is possible to reduce the use of expensive protein sources (such as fishmeal) with cheaper carbon and nitrogen sources (such as wheat bran and animal excreta respectively) in tilapia feed with growth equivalent to high protein pelleted feed. Tilapia Fish farmers could therefore reduce feed cost in their farms by the introduction of a cheap carbon source (such as wheat bran) and organic wastes e.g. poultry waste, cow dung to generate microbial protein in the pond on which $O$ niloticus will rely as source of food.

\section{REFERENCES}

Akinwade, A.A., Moody, F.O., Sogbesan, O.A., Ugwumba, A.A.A., Ovie, S.O.(2004). Haematological response of Heterobranchus longifilis fed varying dietary protein levels. Proc. Fish. Soc. Of Nig. (FISON). Pp 713-717. 
Agric. Biol. J. N. Am., 2011, 2(6): 902-906

Ansa, E. J; Jiya, J. (2002). Effect of pig manure on the growth of Oreochrohus niloticus under integrated fishcum pig farming system. Journal of Aquatic Sciences, 17 (2) 85-87.

Avnimelech Y.; Mokady, S. (1986) Circulated pond as efficient bioreactors for single cell protein production. Journal of Aquaculture 41 (2) 58-66.

Avnimelech, Y., Mokady, S. and Schroeder, G. L. (1989). Circulated ponds as efficient bioreactors for Single Cell Protein production Israel J. Aquaculture-Bamidgen. 41 (2) $58-60$.

Blaxhall, P.C. and Daisley, K.W. (1973). Routine hematological method for use with fish blood. J. Fish Biol. 5; 771 - 781.

Brown, B.A. (1980). Haematology. Principles and procedures. Henry Kinpton publishers London. Pp. 358.

Dacie, J. V. and Lewis, S. Lewis, S. M. (1975). Practical haematology $9^{\text {th }}$ ed, Churchill Livingstone New Yoke.

Greene, D.H.S. and Selivonclick, D.P (1990). Effects of dietary vegetable, animal and marine lipid on muscle lipid and haematology of rainbow trout (Oncorhynchuis mykiss). Aquaculture 89, $165-182$.

Klinger, C.R.; Blazer, V.S.; Echerrarin, C. (1996). Effects of dietary lipid on the haematology of channel catfish, Ictalurus punctatus. Aquaculture 147: 225 - 233.

LeRay, C., Nonnotte, G. and Nonotte, L. (1986). The effect of dietary lipids on the trout erythrocyte membrane. Fish physiol. Biochem. 1: 27 - 35.

Li, P. and Gatlin, D. M. III (2003). Evaluation of brewers yeast (Saccharomyces Cerevisiae) as a feed supplement for Hybrid stripped Bass (Morone Chrysops M. Saxatilis). Aquaculture 219:618-692.

Oliva-Teles, A. and Goncalves, P. (2001). Partial replacement of fishmeal by brewers years (Saccharomyces Cerevisiae) in diets for sea bass
(Dicentrarchus Labrax) Juveniles. Aquaculture 202:269-278.

Olvera-Novoa, M. A. Martines-Palacios C. A. and OliveraCastillo, L. (2002). Utilization of Torrla yeast (Candida utilis) as a protein sources in diets for tilapia (Oreochromis mossambicus Peters) fry. Aquacult. Nutr. 8:257-264.

Salami, A.A.; Oluayo-Bello, O.O and Folake, L. (1992). The effects of dietary treatment on the morphometric and haematological characteristics in Clarias gariepinus. Proc. Fish Soc. Nig.

Sanchez-Muniz, F.J., dela Higuera, F.J. Mataix and G. Varela (1979). The yeast Hansenula anomala as a protein source for Rainbow trout (Salmo gairdneri). Haematological Aspects. Comp. Biochem Physiol. 63; $153-157$

Schroeder, G. L. (1978). Autotrophic and Heterotrophic Production of Micro-organism in intensively manured fish ponds and related fish yield. Aquaculture 14:303325.

Snienszko, S.F. (1960). Microhaematocrit as a tool in fishery research and management Spec. Scient. Rep. U.S. Fish WildL. Serv., No. 341.

Wahua, T.A.T. (1999). Applied statistics for Scientific Studies. African Link books Ltd. Ibadan. pp. 356.

Wedemeyer, G.A. Mcleay, D.J. and Goodyear, C.P. (1984). Asseessing the tolerance pf fish and fish populations to environmental stress: the problems and methods of monitoring. Pages $163-195$ In: V.W. Cairns, P.V. Hodson and J. O. Nriagu (eds). Contaminant effects on fisheries, Wiley, Toronto.

Wise, D.J., Tomasso, J.R., Gatlin, D.M., Bai, S.C. and Blazer, V.S. (1993). Effects of dietary selenium and vitamin $E$ on red blood cell peroxidation, glutathione peroxidase activity, and macrophage superoxide anion productions in channel catfish J. Aquat. Anim. Health. 5: $177-182$. 